\title{
Nigericin-induced Death of an Acidophilic Bacterium
}

\author{
By ARTHUR A. GUFFANTI, LYNN F. DAVIDSON, \\ TOBE M. MANN AND TERRY A. KRULWICH \\ Department of Biochemistry, Mount Sinai School of Medicine of the \\ City University of New York, New York 10029, U.S.A.
}

(Received 20 November 1978; revised 5 February 1979)

\begin{abstract}
At an external $\mathrm{pH}$ of $3 \cdot 5$, nigericin (which catalyses an electroneutral $\mathrm{H}^{+} / \mathrm{K}^{+}$exchange) abolished the transmembrane proton gradient $(\Delta \mathrm{pH})$ of Bacillus acidocaldarius, causing a rapid acidification of the cytoplasm from approximately $\mathrm{pH} 6 \cdot 0$ to $\mathrm{pH} 3 \cdot 5$. A pronounced loss of viability and fine-structural changes rapidly followed treatment with nigericin. A marked decline in respiration and an even more rapid decrease in cytoplasmic ATP were observed. Activity of at least one cytoplasmic enzyme decreased more slowly. There was no generalized loss in the integrity of the cytoplasmic membrane, as assayed by permeability to inulin or $\mathrm{Na}^{+}$or by release of ultraviolet light-absorbing compounds. The loss of viability upon treatment with carbonyl cyanide $m$-chlorophenylhydrazone was similar to that observed with nigericin, so proton influx alone, rather than together with $\mathrm{K}^{+}$efflux, was probably involved in the death of the organism. Moreover, acidification of the cytoplasm rather than abolition of the $\Delta \mathrm{pH}$ was the lethal event, since no loss of viability was observed when the $\Delta \mathrm{pH}$ was abolished by elevation of the external $\mathrm{pH}$.
\end{abstract}

\section{INTRODUCTION}

In accord with Mitchell's chemiosmotic hypothesis $(1961,1963)$, bacteria generate, via respiration and/or ATP hydrolysis, a protonmotive force generally consisting of a transmembrane $\mathrm{pH}$ gradient $(\Delta \mathrm{pH}$, exterior acid) and a transmembrane electrical potential ( $\Delta \psi$, exterior positive). The protonmotive force, in turn, energizes a variety of energyrequiring processes, as reviewed by Harold (1977). When we became interested in the protonmotive force in acidophilic bacteria, it was with the expectation that such organisms would maintain extremely large $\mathrm{pH}$ gradients across the membrane. Thus, bacteria which could grow at external $\mathrm{pH}$ values of 2 to 3 would presumably require cytoplasmic $\mathrm{pH}$ values much closer to neutrality in order to maintain viability. The consistently large $\Delta \mathrm{pH}$ resulting from this requirement would, moreover, probably preclude the existence of any appreciable $\Delta \psi$, exterior positive. In fact, the occurrence of a 'reversed' $\Delta \psi$, i.e. interior positive, seemed a likely adaptation in such organisms.

Our own studies with Bacillus acidocaldarius (Krulwich et al., 1978) and those of others with different acidophiles (Hsung \& Haug, 1975, 1977; Searcy, 1976) have indeed shown that such organisms maintain a cytoplasmic $\mathrm{pH}$ of greater than 5 , thus generating large $\Delta \mathrm{pH}$ values, and concomitantly exhibiting reversed $\Delta \psi$ values. The assumption that organisms would need to maintain cytoplasmic $\mathrm{pH}$ values much closer to neutrality than a highly acidic milieu appeared validated. Thus, if the large $\Delta \mathrm{pH}$ in an acidophile such as $B$. acidocaldarius were abolished so that rapid acidification of the cytoplasm occurred, viability of the organism would be threatened. In the study presented here, nigericin was used to abolish the $\Delta \mathrm{pH}$ in $B$. acidocaldarius and the ensuing death of the organism was monitored and characterized. The results indicated that the constraints imposed by a lower cytoplasmic $\mathrm{pH}$ limit upon viability are quite severe. 


\section{METHODS}

Organism and growth conditions. Bacillus acidocaldarius ATCC 27009 was grown with shaking at $50{ }^{\circ} \mathrm{C}$ in a basal salts medium adjusted to $\mathrm{pH} 3.5$ (Krulwich et al., 1978). Lactose (25 mM) was added from a separate sterile solution whose $\mathrm{pH}$ was adjusted to $3 \cdot 5$. Solid medium contained the same salt solution and lactose, with the addition of $1 \%(\mathrm{w} / \mathrm{v})$ purified agar. The agar was autoclaved separately and mixed with the salt solution at $50^{\circ} \mathrm{C}$, after which Petri plates were poured.

Chemicals. [carboxy-14 C]Acetylsalicylic acid, $\left[{ }^{3} \mathrm{H}\right]$ inulin $\left(100 \mathrm{mCi}{ }^{-1}\right),{ }^{22} \mathrm{NaCl}$ (carrier-free) were purchased from New England Nuclear. Potassium $\left[{ }^{14} \mathrm{C}\right]$ thiocyanate $\left(40 \mathrm{mCi} \mathrm{mmol}^{-1}\right)$ was from The Radiochemical Centre, Amersham. Firefly tails, carbonyl cyanide $m$-chlorophenylhydrazone (CCCP), ATP (disodium salt) and $o$-nitrophenyl- $\beta$-D-galactopyranoside were from Sigma. Nigericin was the generous gift of Dr H. R. Kaback. All other chemicals were obtained commercially at the highest purity available.

Treatment with nigericin. Exponentially growing organisms were washed twice at room temperature with $25 \mathrm{~mm}$-sodium citrate buffer, $\mathrm{pH} 3.5$, and suspended in that buffer to give $0.05 \mathrm{mg}$ bacterial protein $\mathrm{ml}^{-1}$. The suspensions were incubated with shaking at $50{ }^{\circ} \mathrm{C}$ for $10 \mathrm{~min}$. Nigericin (in ethanol) was then added to a final concentration of $0.2 \mu \mathrm{M}$, and samples were taken at intervals. For measurements of viability, the nigericin-treated organisms were rapidly diluted $\left(1\right.$ in $\left.10^{4}\right)$ in $25 \mathrm{~mm}$-sodium citrate, $\mathrm{pH} 3 \cdot 5$, and plated on solid media. For measurements of ATP, oxygen consumption, $\beta$-galactosidase $(\beta$-D-galactoside galactohydrolase; EC 3.2.1.23) activity and uptake of various solutes, the samples were filtered through Millipore type HA filters $(0.45 \mu \mathrm{m}$ pore size) and washed with $25 \mathrm{~mm}$-sodium citrate, $\mathrm{pH} 3.5$. Organisms were collected from the filters, suspended in citrate buffer and used for the appropriate assay.

Addition of $0.2 \mu \mathrm{M}$-nigericin, under the conditions described, totally dissipated the transmembrane $\Delta \mathrm{pH}$ within $5 \mathrm{~s}$ (Krulwich et al., 1978). Measurements of the $\mathrm{pH}$ of the medium indicated that the $\mathrm{pH}$ of the suspension increased by less than $0.02 \mathrm{pH}$ units. Thus, the nigericin treatment rapidly reduced the cytoplasmic $\mathrm{pH}$ from approximately $6 \cdot 0$ to $3 \cdot 5$. On the other hand, measurements of the transmembrane $\Delta \psi$ indicated no change during the nigericin treatment from a value of $35 \mathrm{mV}$ (interior positive).

Every experiment with nigericin included a control in which organisms were incubated under the same conditions in the absence of nigericin. All the data represent average values from no fewer than three separate experiments.

Assays. Cytoplasmic ATP was extracted with $\mathrm{HClO}_{4}$ (Cole et al., 1967) and measured by the firefly assay (Stanley \& Williams, 1969) in a Beckman LS-230 spectrometer, as described elsewhere (Krulwich et al., 1978). Determinations of oxygen consumption were made by placing $3 \mathrm{ml}$ of bacterial suspension in a Yellow Springs Instruments model $\mathbf{J} 3$ oxygen monitor attached to a Beckman chart recorder. Lactose was added to a final concentration of $3 \mathrm{~mm}$, and the suspensions were incubated with stirring in the measuring chamber for $5 \mathrm{~min}$. Oxygen uptake was monitored for 5 to $10 \mathrm{~min}$ at $50^{\circ} \mathrm{C}$. $\beta$-Galactosidase was assayed according to the method of Craven et al. (1965). The proton gradient across the membrane $(\Delta \mathrm{pH})$ was measured by the distribution of [carboxy-14 C]acetylsalicylic acid $\left(55 \mu \mathrm{M}, 125 \mu \mathrm{Ci} \mathrm{mg}{ }^{-1}\right)$ at $50{ }^{\circ} \mathrm{C}$ in a flow dialysis apparatus (Ramos et al., 1976) as described elsewhere (Krulwich et al., 1978). The transmembrane electrical potential $(\Delta \psi)$ was measured as described previously (Krulwich et al., 1978) by the uptake of $\mathrm{KS}^{14} \mathrm{CN}(2.5 \mathrm{mM}$, $\left.0.25 \mathrm{Ci} \mathrm{mmol}^{-1}\right)$. The uptake of ${ }^{22} \mathrm{NaCl}$ or $\left[{ }^{3} \mathrm{H}\right]$ inulin was measured using a filtration assay at $50{ }^{\circ} \mathrm{C}$ as described previously for methyl thio- $\beta$-D-galactoside uptake (Krulwich et al., 1978). Protein was determined by the method of Lowry, using lysozyme as the standard.

Electron microscopy. Organisms were fixed by the method of Kellenberger et al. (1958), dehydrated in a graded series of alcohols and embedded in Epon 812 (Luft, 1961). Sections were cut on a Porter-Blum MT-2 ultramicrotome with a diamond knife and stained with uranyl acetate and lead citrate (Reynolds, 1963). The specimens were examined in a JEOL 100 electron microscope at $80 \mathrm{kV}$.

\section{RESULTS AND DISCUSSION}

Bacillus acidocaldarius was treated with nigericin under conditions in which, as described in Methods, the transmembrane $\Delta \mathrm{pH}$ was abolished and the cytoplasm was rapidly acidified to $\mathrm{pH} 3 \cdot 5$. This treatment resulted in death of the organisms (Fig. 1). More than $50 \%$ of the colony-forming capacity was lost after $5 \mathrm{~min}$ nigericin treatment. Organisms incubated under similar conditions in the absence of nigericin exhibited a definite, though much smaller and more variable, loss of viability over $2 \mathrm{~h}$. Examination of thin sections by electron microscopy (Fig. 2) revealed that B. acidocaldarius has morphological features typical of bacilli, but after 2 min nigericin treatment there was a marked change in the 


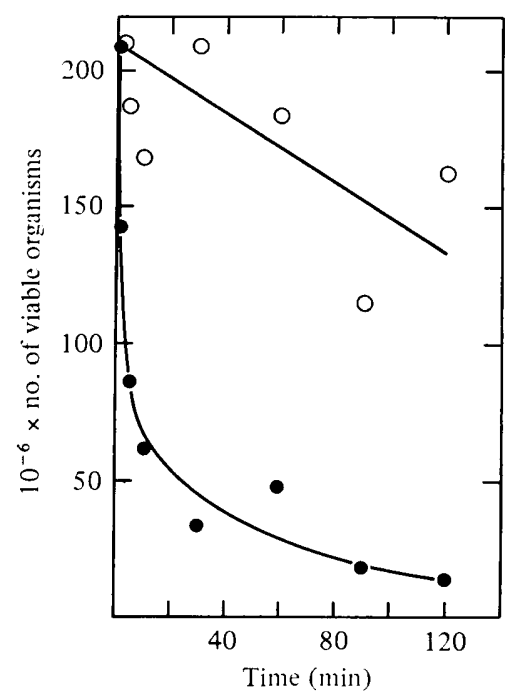

Fig. 1. Effect of nigericin on the viability of $B$. acidocaldarius. Organisms suspended in $25 \mathrm{~mm}-$ sodium citrate, $\mathrm{pH} 3 \cdot 5$, were incubated at $50^{\circ} \mathrm{C}$ in the absence $(\mathrm{O})$ or presence $(O)$ of $0.2 \mu \mathrm{M}$ nigericin. Samples were taken at the indicated times to determine the number of colony-forming units.

appearance of the cytoplasm. Septa, mesosomes, a nuclear region and a rather homogeneous cytoplasm were all discernible in control cultures (Fig. $2 a$ ). After 2 min nigericin treatment, a nuclear region and mesosomes were no longer discernible and the cytoplasm appeared to contain aggregates of particulate material which previously had been homogeneously distributed (Fig. 2b). Septa were still observed in some organisms, and the cytoplasmic membrane and walls appeared intact but separated by a distinct gap. Incubation of control and nigericin-treated cultures for another $30 \mathrm{~min}$ did not cause any further changes in morphology (results not shown).

Respiratory activity and cytoplasmic ATP content declined rapidly to very low levels on treatment with nigericin (Figs 3, 4). The decline in ATP was especially rapid, further experiments showing it to be complete within $1 \mathrm{~min}$ after the addition of nigericin (results not shown). An appreciable, though much slower, decline in ATP occurred in control organisms incubated in the non-nutrient buffer in the absence of nigericin (Fig. 4). Presumably there is a gradual loss of the $\Delta \mathrm{pH}$ with concomitant acidification of the cytoplasm in the control organisms, although this was not examined. The ATP lost from treated and untreated organisms did not appear in the medium. Perhaps acidification of the cytoplasm stimulated the hydrolytic activity of adenosinetriphosphatase (ATP phosphohydrolase; EC 3.6.1.3) resulting in rapid hydrolysis of cytoplasmic ATP.

Several determinations failed to indicate any generalized loss of membrane integrity. In addition to the failure to detect release of ATP, there was no release of compounds absorbing at 260 or $280 \mathrm{~nm}$, nor was there any increase in cell permeability to inulin or $\mathrm{Na}^{+}$following treatment with nigericin. There was, however, a significant decrease in the activity of a cytoplasmic enzyme, $\beta$-galactosidase, after nigericin treatment. This decrease was slower than the effect of nigericin on viability, respiration or ATP, and control organisms exhibited a decrease in $\beta$-galactosidase activity that was almost as great (results not shown).

Since nigericin abolishes the transmembrane $\Delta \mathrm{pH}$ by facilitating an electroneutral exchange of $\mathrm{H}^{+}$and $\mathrm{K}^{+}$(Asghar et al., 1973; Harold \& Baarda, 1968), the effects observed were possibly due to $\mathrm{H}^{+}$influx and/or $\mathrm{K}^{+}$efflux rather than solely to $\mathrm{H}^{+}$influx. The effect of CCCP on the viability of $B$. acidocaldarius was therefore examined. This proton conductor abolishes the $\Delta \mathrm{pH}$ in $B$. acidocaldarius (Krulwich et al., 1978) and other organisms by 


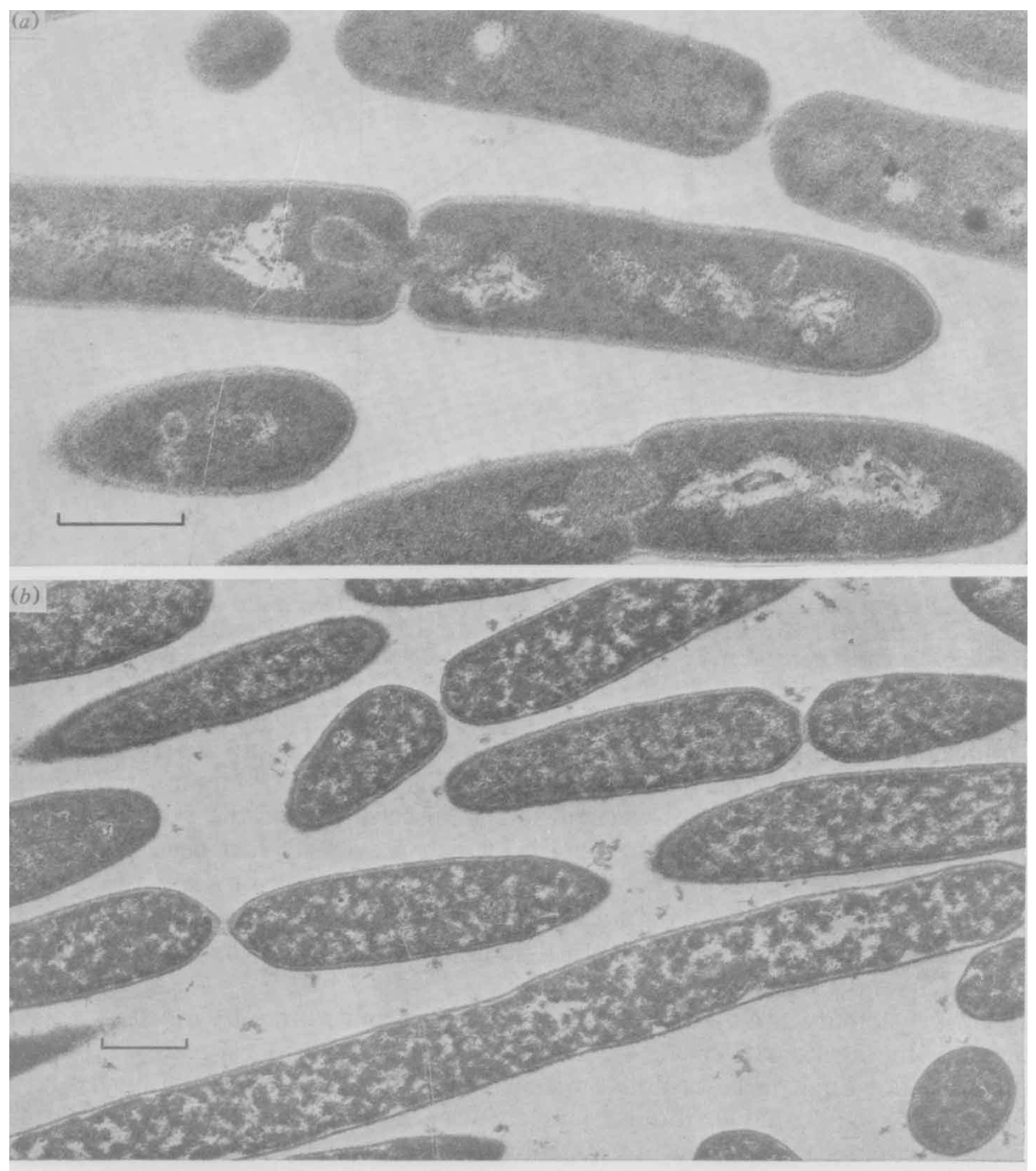

Fig. 2. Electron micrographs of organisms from control and nigericin-treated suspensions. The bacteria were incubated for $2 \mathrm{~min}$ at $50^{\circ} \mathrm{C}$ in $25 \mathrm{~mm}$-sodium citrate buffer, $\mathrm{pH} 3.5$, in the absence (a) or presence $(b)$ of $0 \cdot 2 \mu \mathrm{M}$-nigericin. Bar markers represent $0.5 \mu \mathrm{m}$.

facilitating an electrogenic influx of protons which is not, at least initially, accompanied by a stoicheiometric loss of $\mathrm{K}^{+}$. Under conditions in which $10 \mu \mathrm{M}$-CCCP was used to treat the organisms instead of nigericin, a killing curve was generated that was identical to that found with nigericin (results not shown). It was still possible, however, that while proton influx was the critical factor in nigericin-induced death of $B$. acidocaldarius, the abolition of the $\Delta \mathrm{pH}$ per se, rather than acidification of the cytoplasm, was the crucial event. Therefore, a series of incubations was conducted in buffers of increasing $\mathrm{pH}$ such that the $\Delta \mathrm{pH}$ would be diminished and finally abolished without acidification of the cytoplasm. As shown in Table 1, incubation of organisms for $10 \mathrm{~min}$ at $\mathrm{pH}$ values as high as 6.0 (at which $\Delta \mathrm{pH}$ would be zero) did not cause a loss of viability. The effect of nigericin diminished with increasing external $\mathrm{pH}$. This decrease in effect was especially dramatic above $\mathrm{pH} 4 \cdot 5$, which is also close to the upper $\mathrm{pH}$ limit for growth and $\beta$-galactoside transport (Krulwich et al., 1978). That this $\mathrm{pH}$ value is a transition point may relate to the $\mathrm{pK}$ of amino acid 


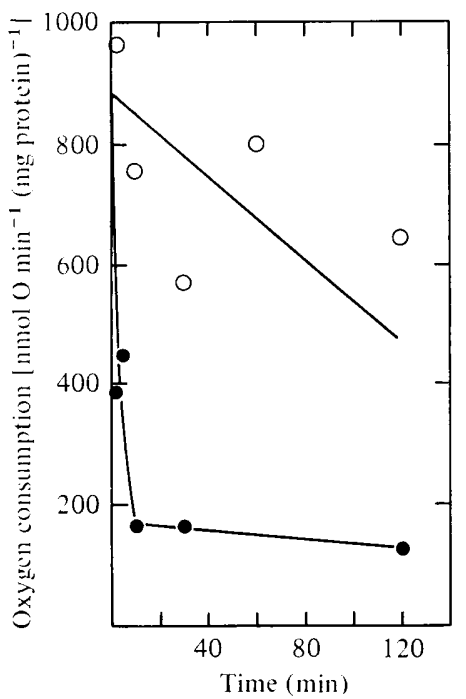

Fig. 3

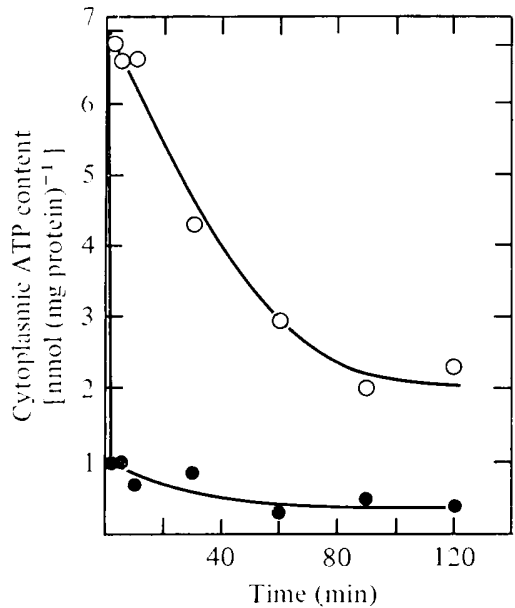

Fig. 4

Fig. 3. Effect of nigericin treatment on oxygen consumption by $B$. acidocaldarius. Organisms were incubated at $50^{\circ} \mathrm{C}$ in $25 \mathrm{~mm}$-sodium citrate buffer, $\mathrm{pH} \mathrm{3.5}$, in the absence $(O)$ or presence $(O)$ of $0.2 \mu \mathrm{M}$-nigericin. Samples were taken at the indicated times and assayed for oxygen consumption in the presence of $3 \mathrm{~mm}$-lactose.

Fig. 4. Effect of nigericin on the cytoplasmic content of ATP. Organisms were suspended in $25 \mathrm{~mm}$ sodium citrate buffer, $\mathrm{pH} 3 \cdot 5$, at $50^{\circ} \mathrm{C}$ in the absence $(O)$ or presence $(O)$ of $0.2 \mu \mathrm{M}$-nigericin. Samples were removed at the indicated times and assayed for cytoplasmic ATP content.

\section{Table 1. Effect of external $p H$ on nigericin-induced death}

Organisms were suspended at equal concentrations in $25 \mathrm{~mm}$-sodium citrate buffers at the indicated $\mathrm{pH}$. Nigericin was added to a final concentration of $0 \cdot 2 \mu \mathrm{M}$ to one suspension at each pH. All the suspensions were incubated for $10 \mathrm{~min}$ with shaking at $50^{\circ} \mathrm{C}$, then diluted $\left(1\right.$ in $\left.10^{4}\right)$ in $25 \mathrm{~mm}$ sodium citrate buffer, $\mathrm{pH} 3 \cdot 5$, and plated.

$\begin{array}{cccc}\text { Buffer pH } & \text { Control } & \begin{array}{c}\text { Nigericin- } \\ \text { treated }\end{array} & \begin{array}{c}10^{-6} \times \text { no. of colony-forming } \\ \text { organisms after 10 min } \\ \text { organisms } \\ \text { killed }\end{array} \\ 3.5 & 157 & 32 & 80 \\ 4 \cdot 0 & 159 & 51 & 68 \\ 4 \cdot 5 & 174 & 81 & 53 \\ 5 \cdot 0 & 170 & 123 & 28 \\ 5 \cdot 5 & 166 & 144 & 13 \\ 6.0 & 170 & 138 & 19\end{array}$

residues on both sides of the membrane which could affect membrane function. As shown in Fig. 5, the effect of nigericin also decreased as the incubation temperature was lowered. This was consistent with previous findings in this and other experimental systems (Krasne et al., 1971; Krulwich et al., 1978; Racker \& Hinkle, 1974).

We thank Dr Saul Puszkin and his associates William Bloom and Christine Ores for their help with electron microscopy. This work was supported by research grant PCM 7810213 from the National Science Foundation. Dr Krulwich is the recipient of a Research Career Development Award from the National Institutes of Health. Dr Guffanti is a trainee on Institutional Training Grant GM 07036 from the National Institutes of Health. 


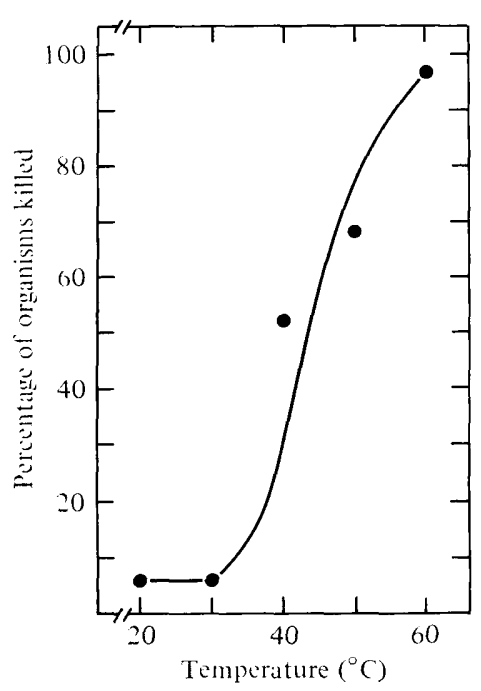

Fig. 5. Effect of nigericin on the viability of B. acidocaldarius at various temperatures. Organisms were suspended at equal concentrations in sodium citrate buffer, $\mathrm{pH} 3 \cdot 5$, and incubated at the temperatures indicated for $10 \mathrm{~min}$ with $0.2 \mu \mathrm{M}$-nigericin. Samples were then removed, plated and colony-forming units were counted.

\section{REFERENCES}

Asghar, S. S., Levin, E. \& Harold, F. M. (1973). Accumulation of neutral amino acids by Streptococcus faecalis: energy coupling by a protonmotive force. Journal of Biological Chemistry 248, 5225-5233.

Cole, H., Wimpenny, J. W. T. \& Hughes, D. E. (1967). The ATP pool in Escherichia coli. I. Measurement of the pool using a modified luciferase assay. Biochimica et biophysica acta 143, 445-453.

Craven, G. R., Starr, E., JR \& Anfinsen, L. B. (1965). Purification, composition and molecular weight of the $\beta$-galactosidase of Escherichia coli K12. Journal of Biological Chemistry 240, 24682477.

HARold, F. M. \& BAARdA, J. R. (1968). Effects of nigericin and monactin on cation permeability of Streptococcus faecalis and metabolic capacities of potassium-depleted cells. Journal of Bacteriology 95, 816-823.

HAROLD, F. M. (1977). Membranes and energy transduction in bacteria. Current Topics in Bioenergetics 6, 83-149.

HsUNG, J. C. \& HAUG, A. (1975). Intracellular pH of Thermoplasma acidophila. Biochimica et biophysica acta 389, 477-482.

Hsúng, J. C. \& Haug, A. (1977). Membrane potential of Thermoplasma acidophila. FEBS Letters 73, 47-50.

Kellenberger, E., Ryter, A. \& Sechaud, J. (1958). Electron microscope study of DNA-containing plasma. II. Vegetative and mature phage DNA as compared with normal bacterial nucleoids in different physiological states. Journal of Biophysical and Biochemical Cytology 4, 671-678.

Krasne, S., Eisenman, G. \& Szabo, G. (1971).
Freezing and melting of lipid bilayers and the mode of action of nonactin, valinomycin and gramicidin. Science 174, 412-415.

Krulwich, T. A., Davidson, L. F., Filip, S. J., JR, Zuckerman, R. S. \& GufFanti, A. A. (1978). The protonmotive force and $\beta$-galactoside transport in Bacillus acidocaldarius. Journal of Biological Chemistry 253, 4599-4603.

LUFT, J. H. (1961). Improvements in epoxy resin embedding methods. Journal of Biophysical and Biochemical Cytology 9, 407-414.

MitChell, P. (1961). Coupling of phosphorylation to electron and hydrogen transfer by a chemiosmotic type of mechanism. Nature, London 191, 144-148.

Mitchell, P. (1963). Molecule, group and electron translocation through natural membranes. Biochemical Society Symposia 22, 142-168.

RACKer, E. \& Hinkle, P. C. (1974). Effect of temperature on the function of a proton pump. Journal of Membrane Biology 17, 181-188.

Ramos, S., Schuldiner, S. \& KabaCK, H. R. (1976). The electrical gradient of protons and its relationship to active transport in Escherichia coli membrane vesicles. Proceedings of the National Academy of Sciences of the United States of America 73, 1892-1896.

Reynolds, E. S. (1963). The use of lead citrate at high $\mathrm{pH}$ as an electron-opaque stain in electron microscopy. Journal of Cell Biology 17, 208-212.

SEARCY, D. G. (1976). Thermoplasma acidophilum: intracellular $\mathrm{pH}$ and potassium concentration. Biochimica et biophysica acta 451, 278-286.

Stanley, P. E. \& Williams, S. G. (1969). Use of the liquid scintillation spectrometer for determining adenosine triphosphate by the luciferase enzyme. Analytical Biochemistry 29, 381-392. 